\title{
The obsession with greatness leads to power abuse: Is spiritual intelligence an appropriate response?
}

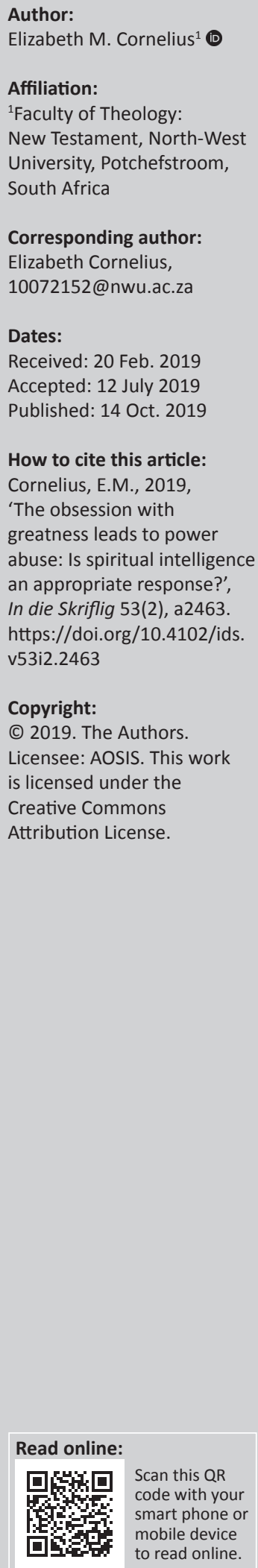

Power abuse is the reason for corruption, violence, murder, rape and many other crimes. This article focuses on the reasons for power abuse - the reasons why people morph into beasts. Some say it is a result of an aspiration for superiority. Others say it is an act of a typical personality type, namely the ruling type. I ask the following question in this regard: Is it an obsession with greatness? What is present or absent in a person's life that makes them obsessed with greatness? Herod the Great is studied as an example of a power abuser in order to determine what brought out the beast in him. The research is done with the help of various disciplines, including history, sociology and psychology in order to answer different questions. It is concluded that an obsession with greatness can be a result of the absence of spiritual intelligence - an absence of religion.

Keywords: Power abuse; Aspiration for superiority; Obsession with greatness; Herod the Great; Spiritual intelligence.

\section{Introduction}

The actress, Meryl Streep, criticised Donald Trump at the 74th Golden Globe Awards in January 2017. In her lifetime achievement speech, Streep took dead aim at Trump when she called out his mimicking of a New York Times reporter with a disability, which was, according to many, a deliberate attempt to mock the reporter. Streep (in Howard 2017:n.p.) said that:

... this instinct to humiliate, when it's modelled by someone in the public platform, by someone powerful, it filters down into everybody's life, because it kind of gives permission for other people to do the same ... Disrespect invites disrespect, violence incites violence, when the powerful use their position to bully others, we all lose.

In these days in our society, it is often said that power corrupts. World history also provides many examples of the abuse of power. Lavrentiy Beria operated just under Stalin during World War II, and abused his position of power by driving around Russia in his limousine and picking out women who he would take to his mansion and rape (Knight 1993:155-175). Josef Mengele was given access to the thousands of inmates passing through Auschwitz to experiment on. He would, for example remove a boy's kidney without anaesthesia, simply to see what would happen (Kubica 1998:317-337). Christian VII of Denmark slapped people across the face whenever he felt like it (Stevens 2012). The Roman emperor, Commodus, who reigned from AD 180 to 192, murdered unarmed men in arenas and slaughtered hundreds of wild animals for fun to prove how great he was (Reese 2015). Emperor Nero, who ruled from AD 54 to 68 murdered his own mother, his first wife and (allegedly) his second wife (Jarus 2013). Emperor Caligula also known as the worst Roman emperor - ruled from AD 37 to 41 and had a crowd that gathered at the Colosseum thrown to animals after he had their tongues cut out (Reese 2014).

In South Africa, the saying that power corrupts, has been on everybody's lips lately. Already in 2010, Brkic (2010) states that the abuse of power by politicians was threatening to pull South Africa apart. He says that 'the days in South Africa are growing progressively darker', and that 'the leading lights of the ANC reveals an appetite for abuse of power'.

On News24 on 31 August 2015, the DA's leader, Mmusi Maimane, said: 'we must protect SA from Zuma's abuse of power'. Blade Nzimande, General Secretary of the South African Communist Party, delivered the South African Communist Party's message of support at COSATU's central committee meeting in Pretoria, and hit out at President Zuma, calling his latest cabinet reshuffle an abuse of power (Manyathela 2017). In The Citizen of 10 October 2017, Eric Naki reported different calls from a number of influential individuals for Zuma's powers to be curtailed,

Note: This contribution is collected as part of the 'Marianne Dircksen Festschrift', sub-edited by Johan Steenkamp (North-West University). 
both from within and outside the ANC. According to Naki, Zuma's abuse of his presidential powers in order to pursue his personal agenda, his appointment of incompetent people to key positions, and his firing of finance minister, Pravin Gordhan (which resulted in the rand's value dropping and the country being downgraded to junk status by international ratings agencies), brought influential people like Professor Susan Booysen, a political analyst, to say that Zuma acts as if he is the only one (citation).

President Trump commented on the land issue in South Africa and said that land expropriation in South Africa will be monitored by his administration (Shange 2018). On 24 August 2018, Siviwe Feketha (2018) of IOL News reported that the ANC's head of the presidency, Zizi Kodwa, told The Star that the ANC was going ahead with the expropriation of land without compensation. From the report, it is clear that Kodwa blames Trump for power abuse, as he stated that Trump is not the president of the world, only the president of the USA, and cannot interfere with the domestic affairs of another country.

From the examples above it is clear that, when society is prejudiced or negatively affected or pressured, or harmed by a person in a leadership position, very often it is a result of that person's power abuse. This article will make use of different relevant disciplines in order to answer different questions and to investigate the following three aspects:

- the terms power and authority as discussed by sociologists;

- the psychology of power as discussed by psychologists; and

- Herod the Great's socio-historical use and abuse of power as described by historians.

Although it is acknowledged that power use and abuse can be differently interpreted in different cultures, a further aim of this article is to interpret the psychology behind Herod's power abuse from a psychological perspective, and to further investigate the role that religion and spiritual intelligence - the Christian religion taken as an example can play in preventing power abuse in society.

\section{An interpretation of power and authority}

There is no consensus about the meaning of the concepts power and authority among scholars. For Weber (1947:28), power is the 'probability that one actor within a social relationship will be in a position to carry out his own will despite resistance, regardless of the basis on which this probability rests'. For Crossman (2016) it is the ability to control others, events or resources; to make happen what one wants to happen in spite of obstacles, resistance or opposition. I would add that, if someone is taking power, he or she is taking the superordinate position. Crossman says power is thus a thing that is held, coveted, seized, taken away, lost or stolen, and it is used in what are essentially adversarial relationships, involving conflict between those with power and those without.

Weber (1947:28) considers authority, on the other hand as the 'probability that a command with a given content will be obeyed by a given group of persons'. The major difference between power and authority for Weber, Coleman (1997:31) says, rests in the fact that power is essentially tied to the personal characteristics of individuals or groups, whereas authority is always tied to social positions or roles. While power is then a merely factual relation, authority is a legitimate relation of domination and subjection. Bierstedt (1964:79) describes authority as sanctioned power or institutional power. For Coleman (1997:32), in authoritative relations the right to command (and the probability of obedience) exists as a settled mutual expectation, independent of any specific person who occupies the office of manager, civil servant or army officer.

Weber (1958:1-11) differentiates between three (ideal) types of authority relations, namely traditional authority, charismatic authority and rational-legal authority. The first type, traditional authority, is a legitimate form of authority and grounds its legitimacy by reference to its connection to the past, and justifies its actions by claiming that they conform to precedents. Traditional authority tends to be conservative and intrinsically lacks any inner motor for social change. Traditional authority, which includes patrimonial, feudal and monarchical-bureaucratic regimes, has held sway over a large part of human history and of the earth's surface. Statements such as ' $[a]$ s the ancients taught us'; '[ $a]$ s our originating sacred document declares' and ' $[a] \mathrm{s}$ the founding fathers saw', are typical motifs and appeals within traditional authority systems. As we will see, traditional forms of authority never fully fade away. All authority rests on some variant of tradition or gets related back to it.

The second type of authority, charismatic authority, rests on the wisdom or even the sacred gifts of an extraordinary individual and his followers. The charismatic leader breaks with tradition: 'You heard it said of old, but I say unto you'. From the vantage point of the beliefs of the charismatic leader and his or her followers, charismatic authority does not derive from the consent of the governed. The charismatic leader's unusual gifts or direct conduit to God are regarded as compelling and self-justifying. In that sense, charismatic authority is non-rational (which does not mean irrational). The charismatic authority could break with authority that is based on traditions by an appeal to a higher power. Jesus is an example of a charismatic leader.

The final type of authority, rational-legal authority, is embodied in formal bureaucracy, the rule of law, the appeal to efficiency, and the rational fit between means and intended goals. Properly followed procedures displace the personal rule of charismatic authority (based mainly on witness and virtuosity) or the substantive traditions of 
traditional authority. Like charismatic change, rationallegal authority systems allow for social change, but unlike charismatic change, in rational-legal authority systems, change is orderly, incremental and constrained by procedure, law and scientific calculation. Indeed, Weber feared that this modern form of authority might become a kind of iron cage, devoid of spirit and radical possibility.

In sum, Coleman (1997:32) states that authority is legitimate power. Power need not be consensual; authority must be. He explains that a demagogue may, for example, exert power over groups of individuals whose motivations he or she manipulates, or actions he or she controls. In the same way, a dictator may cow (or even physically coerce) people into acquiescing to his or her commands. But the control of a manager over workers, of the civil servant over clientele, or of an army officer over soldiers, is authority.

Coleman (1997:33) warns that even legitimate power is never simply neutral or totally benign. There takes place, almost universally, a fusion of authority and mere power which can lead to or intensify intragroup conflicts. This fusion also serves to delegitimise authority when it is seen to exceed its bounds of legitimacy.

Why then would powerful people in authoritative positions move into negative directions? How can this be explained by the field of psychology?

\section{The psychology of power}

In psychological science, power is defined as one's capacity to alter another person's condition or state of mind by providing or withholding resources such as food, money, knowledge and affection, or administering punishments such as physical harm, job termination or social ostracism (Keltner 2007).

Lehrer (2010) made an interesting remark when he wrote about the bad news of power. He says that once a person is at the top of the social ladder, he ends up morphing into a very different kind of beast. Why do people at the top, with authority and power, suddenly morph into beasts? Keltner (2017) says that when you give people power, they basically start acting like fools. Once people assume positions of power, they are likely to act more selfishly, impulsively and aggressively, and they have a harder time seeing the world from other people's points of view. Kelter did his own research and found that people with power tend to behave like patients who have damaged their brain's orbitofrontal lobes (the region of the frontal lobes right behind the eye sockets) - a condition that seems to cause overly impulsive and insensitive behaviour. Thus, the experience of power might be thought of as having someone opening your skull and taking out that part of your brain so critical to empathy and socially appropriate behaviour. Keltner also refers to the wealth of evidence that having power makes people more likely to act like sociopaths.
Psychologists refer to this as the 'paradox of power'. It means that the very traits that helped leaders accumulate control in the first place, all but disappear once they rise to power (see Keltner 2007). According to Keltner (2007), this is a result of a damaged social intelligence.

The question why a person's social intelligence is damaged, still remains unanswered. It could be an aspiration for superiority, as discussed by Alfred Adler (1979:29-40). While an aspiration for superiority can motivate you to work very hard, for some this aspiration can go wrong, and they may end up being arrogant and selfish, committing crimes and abusing power.

So why do people strive for superiority? Adler (1979:50-58) believes that some people might strive for superiority because of a sense of inferiority. What is also relevant in this argument is Adler's personality types, especially the ruling type. People who belong to the ruling personality type are characterised early on by a tendency to be generally aggressive and dominant, and possess an intense energy that overwhelms anything or anybody who gets in their way.

The question regarding why a person with a ruling personality type (perhaps struggling with inferiority issues) would strive for superiority and abuse power, remains. My question is whether this is an obsession with greatness. What is present or absent in leaders' lives that makes them obsessed with greatness? In the next section, Herod the Great will be studied to determine what brought out the beast in him.

\section{Herod the Great}

Herod the Great is considered as an example of a person who abused his power. Riley (2003) refers to Herod the Great as one of the biblical examples of people who became corrupt when too much power was given to them. He says that Herod is an example of the abuse of power and authority that resulted in the corruption of his moral character.

\section{Background of the life and career of Herod the Great}

Herod was born in $73 \mathrm{BC}$ as the son of Antipater from Idumea and his wife, Cyprus, the daughter of an Arabian sheik. Antipater was a key figure in the internal politics of Judea. He proved himself to be a friend of the Romans and as a result, he received the privilege of a citizen of Rome and freedom from taxes everywhere (Jewish Antiquities, book xiv:8.4). Later he was made procurator of Judea by Julius Caesar (Jewish Antiquities, book xiv:8.5).

Antipater managed to secure the appointment of his sons as governors: his eldest son in Jerusalem, and Herod in Galilee in 47 BC (Josephus Jewish Antiquities, 14.9.2). This was the beginning of Herod's career as ruler. Herod enjoyed the support of Rome, but he was infamous for his brutal decisions and for being too arrogant. His brutality was 
condemned by the Sanhedrin. However, he showed his leadership qualities through many military victories.

In $37 \mathrm{BC}$, Herod was unexpectedly appointed by the Roman senate as king of the Jews in Judea (Josephus, BJ, 1.14.4), as they expected him to support the interests of his Roman patrons. His support from the Roman Empire was a major factor that enabled him to maintain his authority. During his 33-year reign, Herod proved himself to be both able and ruthless (Jeffers 1999:123). As king, he was well known for his colossal building projects in Judea, such as the construction of the Temple Mount. These projects not only improved his reputation as a leader, but they also created employment opportunities. He developed water supplies for Jerusalem, founded new cities, and exerted a great deal of effort in order to provide for his people in times of need, as in the case of the famine of 25 BC (Jagersma 1985:357). Herod also made many attempts to conform to traditional Jewish laws, although he was sometimes insensitive (by, for example erecting a golden eagle at the entrance of the temple) (Levine 1998:57).

However, everybody resented his excessive taxation. Herod had a constant concern for his reputation, which led him to make expensive gifts, emptying the kingdom's purse as a result(Cohen 1999:269-273). The Pharisees were discontented, because Herod disregarded many of their demands with respect to the building of the temple. The Sadducees opposed him, because he interfered with temple issues (Schiffman 1991:145). He never became popular with the Jewish people who considered him a foreigner whose power rested on the might of Rome (Jeffers 1999:123).

Ryan (2012) tells how heartless, paranoid and bloodthirsty Herod was, and how he committed unimaginable atrocities. The New Testament teaches us that he ordered every boy aged two years or younger in Bethlehem to be killed (Mt 2:1-23) only because he was alarmed at the birth of a new king. He also ordered the deaths of thousands of others, including the high priest, his rivals, grandfather-inlaw, mother-in-law, brother-in-law, uncle, wife, three sons, and anyone else who he distrusted and considered a threat to himself. He would kill anyone to remain in his position of power. He died in 4 BC from illness. He had an obsession with his power as ruler and oppressed many as a result of this obsession.

\section{Where did Herod get his authority?}

Josephus discusses Herod's career (see Josephus, Jewish Antiquities 14.330-491, 15.1-21, 161-196; Jewish War 1.248-357, 386-393, 433-434). From this, it is clear that the authority of Herod the Great was a legal form of authority. He was a Roman client king of Judea from $37 \mathrm{BC}$ to $4 \mathrm{BC}$, and the kingdom prospered under him. He secured his position of political authority for himself by being a friend to the Romans, but also a friend to whoever would come forward as a source of power. The Romans were the key source of Herod's authority. He rose to power and maintained his position through timely manipulations of the contentious geopolitics that defined his day (Schlude 2017). Schlude (2017) illustrates that Herod was even willing to befriend two major authorities at the same time, namely the Romans and the Parthians, and that Herod manipulated his position between these two regional powers.

As husband and father, Herod had almost complete power as a man in a patriarchal society. As husband, Herod was the head of the family and had absolute power over all the members of the household. This power, according to Jeffers (1999:242), even included the power of life and death.

\section{Herod's abuse of power during his reign}

According to Ferguson (1990:36), a client king of the Roman empire, was considered to be a client to the Roman emperor, and held the title of king, only with Rome's sanction. Such a client king was limited in his right to mint coins and could not pursue his own foreign policy. Client kings had the following responsibilities:

- to advance Rome's purpose;

- to pay taxes to Rome;

- to supply auxiliaries and military aid on demand for the Roman army;

- to maintain order and security on the frontiers; and

- to protect trade routes by acting as buffers between the so-called barbarians and the empire.

In internal matters, a client king had the power to manage his own affairs (Ferguson 1990:36). He had total freedom in internal administration, he could levy taxes for his own use, and maintain an army under his own control.

In order to maintain his authority, Herod made sure he remained a friend to the Romans. In internal matters, however, he served himself. He abused his power and the freedom he had in internal affairs.

He had his own security measures to maintain authority (see Cohen 1999:271; Rocca 2009:15-16):

- he used secret police to monitor and report the feelings of the general populace towards him;

- he prohibited protests;

- he had opponents removed by force; and

- he had a bodyguard of two thousand soldiers.

Herod had a taxation system that heavily burdened the Judean people in order to be able to give expensive gifts to secure his reputation (Cohen 1999:269-273).

The Pharisees opposed him, because he ignored their demands with respect to the Temple's construction. The Sadducees complained about Herod's replacement of temple priests with outsiders in an effort to gain support from the Jewish diaspora (Schiffman 1991:145). 
Riley (2003) states that Herod is an example of the abuse of power and authority which resulted in the corruption of his moral character. Graetz (1895:77) called him 'the evil genius of the Judean nation'. Josephus described him as a man who was cruel to all alike, and one who easily gave in to anger and was contemptuous of justice - he was a ruthless murderer with a suspicious temperament (Josephus, Jewish Antiquities, $17.191,19.329,15.299-316)$.

\section{Herod's abuse of power in marriage}

Herod married ten times (Josephus, The Jewish war, 1.562-563; Jewish Antiquities, 17.19-22). Firstly, he married Doris who, along with her child, he later abandoned, and married Mariamne I, the granddaughter of Hyrcanus II, in an attempt to secure his claim to the throne and gain Jewish favour. Later, he accused Mariamne of infidelity and had her executed. He went on to marry eight other women. According to Ferguson (2013:60), Herod chose his wives for their beauty. Only in the case of Mariamne, marrying for the sake of political advantage.

As a husband to his wives, Herod had the traditional authority of a husband. He could marry or divorce as he liked, since the right of divorce belonged to the husband in Jewish law (Ferguson 1987:56-57). Herod thus used this power for his own benefits, no matter how it affected his wives and children. Even his choices of women in his life was ruled by his personal aspiration for power and control. Whenever things did not go his way, he made changes with no sympathy for the affected women or children.

\section{Herod's abuse of power in his family}

Herod had 15 legitimate children, with Antipater II being his eldest son with his first wife, Doris. It is likely that he fathered more children, as female births were generally not recorded at that time. The terrible acts of bloodshed, which Herod perpetrated against his own family, were accompanied by others, equally terrible, against his subjects. He was so paranoid of his regal authority that he did not hesitate to murder numerous members of his own immediate and extended family. His wife, Mariamne, was publicly executed, as was her mother, Alexandra. Earlier, Herod had put to death Hyrcanus, Marianne's grandfather (who incidentally once had saved the king's life). He also executed three of his sons: Alexander, Aristobulus and Antipater. When he had Mariamne executed, he also ordered the execution of all the children he had with her (for a general survey of Herod's activities, see Josephus, Jewish Antiquities, 14-17). Herod had Mariamne's brother, Aristobulus, drowned out of jealousy for the popular enthusiasm he aroused, which Herod perceived as a threat to his own rule (Josephus, Jewish Antiquities, 15.51-56). When he was seriously ill, Herod changed his will twice to benefit different people (Josephus, Jewish Antiquities, 1.668-669; Jewish Antiquities, 17.188-189). One can see how easily it is for power to corrupt the thinking processes of an individual if he is not careful. Herod was clearly paranoid of losing power.

\section{Conclusion: The force behind Herod the Great}

Why did a person at the top, who possessed authority and power, such as Herod the Great, suddenly morph into a beast who murdered and divorced as he wished, so that he could remain in a position of supreme power? In Herod's case, it was not a case of seizing power, but of buying power from the Romans. There was a transaction in which Herod paid with his loyalty and, in return, the Romans gave him legitimate power.

We may ask what was present in Herod's life that moved him to abuse power. In Jewish Antiquities, (16.150-156), Josephus remarked that Herod abused his power as a result of his love for fame and honour. In other words, what was present in Herod's life was a love for fame and honour. We may perhaps say that he had an obsession with greatness. His obsession with greatness led him to levy unreasonable taxes, loot, oppress and murder innocent people.

The next question then will be: What was absent from Herod's life that gave rise to his love for fame and honour? What was missing from his life that brought on his obsession with his own greatness?

It seems possible to reason that a person, who has an obsession with greatness, an obsession to be in a position of power, has perhaps never met or acknowledged a supernatural power in his or her life. That seems to be a good reason to see themselves as the higher power. An obsession with greatness thus seems to be an absence of spiritual intelligence - an absence of religion.

In the next section, religion and spiritual intelligence will be discussed in order to understand the reason for an obsession with greatness, such as that of Herod the Great.

\section{Religion and spiritual intelligence}

Religion is found in all human societies. Throughout history, religion has continued to be a central part of societies and human experience, shaping how individuals react to the environment in which they live. Religion can shape what people think and how they see the world and themselves. Although not all religions share the same set of beliefs, I believe religion helps individuals to understand that there will always be transcendental powers beyond themselves. This realisation that there may be a higher power or powers greater than the self, I like to call 'spiritual intelligence'.

In 2000, many scholars contributed to the spiritual intelligence debate. Emmons (2000a:3-26) asks the question: Is spirituality an intelligence? In the same journal, he wrote an article on the problems and prospects of spirituality and intelligence (Emmons 2000b:57-64). Gardner (2000:27-34) files a case against spiritual intelligence and Mayer (2000:47-56) argues that a spiritual consciousness is not necessarily a spiritual intelligence. Some scholars accepted the existence of such an 
intelligence and proceeded to work with it. George (2006:3-5), for example, writes on the practical application of spiritual intelligence in the workplace. Tipping (2006) wrote a book on spiritual intelligence at work. Scott (2017) wrote on psychology today, and asks once again: 'Is spiritual intelligence a valid concept?'

Newberg et al. (2001:131-132) explain that religion promotes values and therefore it empowers the believer to alleviate stress by granting him or her a sense of control over an uncertain and terrifying world. It offers believers the assurance that their lives have meaning and purpose, that they are not alone in the struggle for survival. However, Cornelius (2014:591) argues that it is not religion as such that provides this power to believers; it only becomes a personal power once the individual makes it a personal choice. If religion is a system that provides the resources for living a good life, then spirituality is different in the sense that it is the process by which individuals recognise the importance of orienting their lives to something nonmaterial that is beyond and larger than themselves, with a dependence on a higher power (Martin \& Carlson 1988:59). In this regard, Kheswa's (2016:176) observation is significant: spirituality is the reason for believing, and religion is the way of believing. In other words, being spiritually intelligent makes a person realise that there is a higher power, and religion provides him or her with something to believe in. According to Cornelius (2014:593), being spiritually intelligent first of all implies that one recognises the existence of a god - the existence of a higher power.

Griffiths (2011-2018) defines spiritual intelligence as a higher dimension of intelligence that activates the qualities and capabilities of the authentic self in the form of wisdom, compassion, integrity, joy, love, creativity and peace. It results in a sense of deeper meaning and purpose combined with improvements in a wide range of important life skills and work skills.

Zohar (2000) discusses the principles of spiritual intelligence of which I would like to mention the following:

- self-awareness: knowing what you believe, knowing what motivates you, and knowing your values;

- being led by vision and values: acting from principles and deep beliefs, and living accordingly;

- having the quality of compassion;

- the celebration of diversity: valuing other people for their differences;

- humility; and

- a sense of vocation.

Being guided by values outside of yourself, trusting a higher power, valuing others and having compassion for others will never leave room for something like an obsession with greatness in your life. Thus, the absence of spiritual intelligence leads to an urge to control things yourself. We can thus conclude by saying that a form of religion can help those in leadership roles to limit themselves and not harm society.

\section{How can a society prevent power abuse?}

Brkic (2010) asks the questions we all ask ourselves: How do we stop this growing abuse of power? How do we make sure we have a government that cares about our country and actually knows what to do about it? These could have been the same questions asked by the Jews under the authority of Herod the Great.

Kheswa (2016) refers to the misconception about leadership identified as the 'destination myth' by Maxwell (2002), namely that one will learn to lead when one reaches the top position. Successful leaders need to learn to lead before they have a leadership position. Kalunga-Banda (2008) writes that Nelson Mandela described power as a double-edged sword that can do harm as much as it can do good. The problem then is not how to use power, but how not to use power. We should therefore ask what is necessary in a leader for him or her to know how not to use power.

Kheswa (2016:83-85) shows that leading yourself is one of the greatest challenges of being a leader. Kheswa discusses the different keys to leading yourself. One of these keys is moral virtues, which provide the leader with a set of character strengths: wisdom, creativity, curiosity, open-mindedness, integrity, humility, love, justice, mercy, hope and spirituality (to mention only a few). This is in line with Keltner's (2016) thinking that compassion and selflessness are the two things that will enable us to have the most influence over others, and that the result will be power as a force for good in the world. In order for a society to vote for leaders, they will have to find those persons with a solid spiritual intelligence. That spiritual intelligence will help the individual to know and respect themselves and those around them. Such a person will develop a compassionate rather than an aggressive attitude, they will relate more deeply to the world around themselves, they will acquire a global vision, and they will see the bigger picture. Buzan (2001) says spiritual intelligence has the power to transform life, civilisation, the planet and the course of history.

I would conclude by saying that spiritual intelligence provides you with a reservoir of honesty and integrity - the good qualities necessary in a good leader who is not obsessed with his or her own greatness, who would not abuse power and harm society. And the entire world, is in need of leaders with such powers!

\section{Acknowledgements}

Thank you for the opportunity to contribute to a festschrift for Marianne Dircksen.

\section{Competing interests}

I declare that I have no financial or personal relationships which may have inappropriately influenced me in writing this article. 


\section{Authors' contributions}

I declare that I am the sole author of this research article.

\section{Ethical consideration}

This article followed all ethical standards for research without direct contact with human or animal subjects.

\section{Funding Information}

This research received no specific grant from any funding agency in the public, commercial, or not-for-profit sectors.

\section{Data availability statement}

Data sharing is not applicable to this article as no new data were created or analysed in this study.

\section{Disclaimer}

The views and opinions expressed in this article are those of the authors and do not necessarily reflect the official policy or position of any affiliated agency of the authors.

\section{References}

Adler, A., 1979, Superiority and social interest: A collection of later writings, 3rd edn., Northwestern University Press, Evanston, IL.

Bierstedt, R., 1964, 'The problem of authority', in M. Berger \& R.M. Maclver (eds.), Freedom and control in modern society, pp. 67-81, Octagon Books, New York.

Brkic, B., 2010, 'Analysis: Abuse of power - Will the ANC save itself?', Daily Maverick 22 February, viewed 29 January 2019, from https://www.dailymaverick.co.za/ article/2010-02-22-analysis-abuse-of-power-will-the-anc-save-itself/.

Buzan, T., 2001, The power of spiritual intelligence, Thorsons, London.

Cohen, S., 1999, 'Roman domination', in H. Shanks (ed.), The Jewish revolt and the destruction of the second temple in ancient Israel, pp. 299-273, Biblical Archaeology Society, Washington, DC.

Coleman, J.A., 1997, 'Authority, power, leadership: Sociological understandings' New Theology Review 10(3), 31-44, viewed 12 March 2017, from http:// newtheologyreview.com/index.php/ntr/article/viewFile/563/746.

Cornelius, E.M., 2014, 'The relevance of Galatians 5:16-26 in the modern "spiritual intelligence" debate', Dutch Reformed Theological Journal 55(3-4), 589-610.

Crossman, A., 2016, Power, viewed 19 February 2017, from http://sociology.about. com/od/P_INdex/g/Power.htm.

Emmons, R.A., 2000a, 'Is spirituality an intelligence? Motivation, cognition, and the psychology of ultimate concern', International Journal for the Psychology of Religion 10(10), 3-26. https://doi.org/10.1207/S15327582IJPR1001_2

Emmons, R.A., 2000b, 'Spirituality and intelligence', International Journal for the Psychology of Religion 10(10), 57-64. https://doi.org/10.1207/S15327582IJPR 1001_6

Feketha, S., 2018, 'Right-winger Trump is not the president of the world, says ANC', IOL News: Politics, viewed 19 February 2018, from https://www.iol.co.za/news/politics/ right-winger-trump-is-not-the-president-of-the-world-says-anc-16716096.

Ferguson, E., 1987, Backgrounds of Early Christianity, Eerdmans, Grand Rapids, MI.

Ferguson, E., 2013, 'The Herodian dynasty', in J.B. Green \& L.M. McDonald (eds.), The world of the New Testament, pp. 54-76, Baker Academic, Grand Rapids, MI.

Gardner, H., 2000, 'A case against spiritual intelligence', Journal for the Psychology of Religion 10(1), 27-34. https://doi.org/10.1207/S15327582IJPR1001_3

George, M., 2006, 'Practical application of spiritual intelligence in the workplace', Human Resource Management International Digest 14, 3-5. https://doi.org/ 10.1108/09670730610678181

Graetz, H, 1895, History of the Jews, V.II., The Jewish Publication Society of America, Philadelphia, PA.

Griffiths, R., 2011-2018, The definition of spiritual intelligence on spiritual intelligence training, viewed 05 February 2019, from https://sqi.co/definition-of-spiritualintelligence/.

Howard, A., 2017, Meryl Streep takes on Donald Trump at Golden Globes, viewed 10 January 2017, from http://www.nbcnews.com/pop-culture/awards/merylstreep-takes-on-donald-trump-at-golden-globes-n704571
Jagersma, H., 1985, A history of Israel from Alexander the Great to Bar Kochba, trans. from the Dutch J. Bowden, SCM Press, London.

Jarus, O., 2013, Emperor Nero: Facts and biography, viewed 24 January 2017, from http://www.livescience.com/40277-emperor-nero-facts.html.

Jeffers, J.S., 1999, The Greco-Roman world of the New Testament era: Exploring the background of early Christianity, InterVarsity Press, Downers Grove, IL.

Josephus, F., 1965, Jewish antiquities, St. Edmundsbury Press, London. (Loeb Classical Library).

Josephus, F., 1976, The Jewish war, St. Edmundsbury Press, London. (Loeb Classical Library).

Kalunga-Banda, M., 2008, Leading like Madiba: Leadership lessons from Nelson Mandela, Double Storey Books, Cape Town.

Keltner, D., 2007, 'The power paradox', Greater Good Magazine: Science-Based insights for a meaningful life, viewed 20 February 2019, from https://greatergood. berkeley.edu/article/item/power_paradox.

Keltner, D., 2016, The power paradox: How we gain and lose influence, Penguin Press, New York.

Kheswa, G.E., 2016, 'Exploring the contribution of spiritual intelligence to leadership in the public sector', PhD thesis, UNISA, Pretoria.

Knight, A., 1993, Beria: Stalin's first lieutenant, Princeton University Press, Princeton, NJ.

Kubica, H., 1998, 'The crimes of Josef Mengele', in Y. Gutman \& M. Berenbaum (eds.), Anatomy of the Auschwitz death camp, pp. 317-337, Indiana University Press, Bloomington, IN.

Lehrer, J., 2010, The psychology of power, viewed 18 February 2017, from https:// www.wired.com/2010/08/the-psychology-of-power/.

Levine, A.J., 1998, 'Visions of kingdoms: From Pompey to the first Jewish revolt', in M.D. Coogan (ed.), The Oxford history of the Biblical world, pp. 52-87, Oxford University Press, New York.

Manyathela, C., 2017, Nzimande hits out at Zuma over 'abuse of power', viewed 13 November 2017, from http://ewn.co.za/2017/05/29/nzimande-hits-out-at-zumaover-abuse-of-power.

Martin, J.E. \& Carlson, C.R., 1988, 'Spiritual dimensions of health psychology', in W.R. Miller \& J.E. Martin (eds.), Behavior therapy and religion: Integrating spiritual and behavioral approaches to change, pp. 57-110, Sage, Newbury Park.

Mayer, J. D., 2000, 'Spiritual intelligence or spiritual consciousness?', Internationa Journal for the Psychology of Religion 10(1), 47-56. https://doi.org/10.1207/ S15327582IJPR1001_5

Maxwell, J.C., 2002, Leadership 101: What every leader needs to know, Thomas Nelson, Nashville.

Naki, E., 2017, Calls to curtail Zuma's powers due to abuse, viewed 13 November 2017 from https://citizen.co.za/news/south-africa/1683063/calls-to-curtail-zumaspowers-due-to-abuse.

Newberg, A., d'Aquili, E. \& Rause, V., 2001, Why God won't go away: Brain science and the biology of belief, Ballantine, New York.

Reese, M.R., 2014, Ancient origins: The madness of Caligula, viewed 24 January 2017 from http://www.ancient-origins.net/history-famous-people/madness-caligula002132

Reese, M.R., 2015, Ancient origins: Commodus outrageous emperor who fought gladiator, viewed 24 January 2017, from http://www.ancient-origins.net/historyfamous-people/ommodus-outrageous-emperor-who-fought-gladiator-002713.

Riley, M., 2003, The abuse of power, viewed 11 January 2017, from http://www. theseeker.org/cgi-bin/bulletin/show.pl?Mike $\% 20$ Riley/The $\% 20$ Abuse $\% 20$ of $\% 20$ power\%20/.

Rocca, S., 2009, The army of Herod the Great, Osprey Publishing, Oxford.

Ryan, P., 2012, Top 10 evil people from ancient times, viewed 11 January 2017, from http://listverse.com/2012/05/30/top-10-evil-people-from-ancient-times/.

Schiffman, L.H., 1991, From text to tradition: $A$ history of second temple and rabbinic Judaism, Ktay Publishing House, Hoboken, NJ.

Schlude, J.M., 2017, 'Herod the Great: Friend of the Romans and Parthians?', viewed 14 January 2019, from https://www.biblicalarchaeology.org/daily/people-cultures-inthe-bible/people-in-the-bible/herod-the-great-friend-of-the-romans-andparthians/.

Scott, A. 2017, Is "spiritual intelligence" a valid concept? viewed 13 May 2019 , from https://www.psychologytoday.com/us/blog/unique-everybody-else/201708/isspiritual-intelligence-valid-concept.

Shange, N., 2018, 'Land expropriation in South Africa will be monitored by Trump's administration', Dispatch Live, viewed 23 August 2018, from https://www. dispatchlive.co.za/politics/2018-08-23-land-expropriation-in-south-africa-willbe-monitored-by-trumps-administration/.

Stevens, K., 2012, Hilariously insane rulers of all time, viewed 24 January 2017, from http://www.cracked.com/article 20170 the 5 most hilariously insane rulers all_time.html.

Tipping, C.C., 2006, Spiritual intelligence at work, Global 13 Publications, Marietta, GA.

Weber, M., 1947, Wirtschaft und Gesellschaft, Grundrisse der Sozialekonomie, 4th edn., J.C.B. Mohr, Tübingen.

Weber, M., 1958, 'The three types of legitimate rule', Berkeley Publications in Society and Institutions 4(1), 1-11.

Zohar, D., 2000, Spiritual intelligence, Cygnus Books, London. 